\title{
Mortality Salience Increases Belief in a Just World but Not Schadenfreude in Response to a Natural Disaster Affecting a Religious Out-group
}

\author{
Jonathan F. Bassett ${ }^{1,}$ and Kelly L. Cate ${ }^{2}$ \\ ${ }^{I}$ Department of Psychological Science, Lander University, South Carolina, USA \\ ${ }^{2}$ Department of Psychological Science, University of North Georgia, USA
}

\begin{abstract}
This study examined the hypothesis derived from Terror Management Theory that reminders of death would influence both belief in a just world and Schadenfreude, in response to reading about members of a religious out-group affect by a natural disaster. Christian students $\left(\mathrm{N}=88, M_{\text {age }}=19.9\right)$ were primed with thoughts of death or dental pain before reading about a natural disaster that destroyed either a Christian Church or an Islamic Mosque. Participants then completed measures of belief in a just world and schadenfreude. Mortality salience did not affect schadenfreude but social desirability may have masked this effect. Mortality salience did increase beliefs in a just world when a natural disaster affected a religious out-group, suggesting that cultural worldview may be buttressed by evidence that bad things happen to proponents of opposing belief systems.
\end{abstract}

Keywords: Mortality salience, Terror Management Theory, Belief in a Just World.

On November 17 of 2013, a category 4 tornado touched down in Washington Illinois destroying hundreds of homes but leaving almost all of the area churches intact; a phenomenon which some interpreted as divine providence, in which God protected the devout [1]. Inversely, in 2005, some outspoken Christian leaders, such as Pat Robertson, described Hurricane Katrina as a divine punishment for America's increasing secularism and immorality on issues such as abortion [2]. These stories exemplify a tendency to seek telos or purpose in the natural world and to imbue natural phenomenon with moral sensibilities. This tendency may stem from a motive to believe in a just world [3] and the need to believe in a just world may operate in the service of reducing existential anxiety [4]. The present study examined how priming existential anxiety would affect people's reactions to natural disasters impacting a religious in-group or a religious out-group.

Lerner described the belief in a just world as the need to perceive the principles governing the universe as operating in ways that are consistent with the human moral sense of fairness [3]. The need to believe in a just world motivates people to believe that people get what they deserve and deserve what they get, such that good things happen to good people and bad things happen to bad people. Perceived violations of this principle create psychological discomfort and lead to defensive attributions such as victim blaming. Lerner posited that belief in a just world is a paramount motive because it affords people relief from the distress

*Address correspondence to this author at the Department of Psychological Science, Lander University, 320 Stanley Ave, Greenwood, SC 29649, USA; Tel: (864) 388-8740; Fax: (864) 388-8732; E-mail: jbassett@lander.edu caused by the perceived suffering of the innocent and because it allows people the ability to maintain their belief that adherence to socially defined moral systems will allow them to achieve their goals and avoid harm. In contrast, Pyszczynski, Greenberg, and Solomon suggested that the basic human motivation is to minimize death anxiety [4]. Consequently, they argued that belief in a just world, like many other social motives, is important because it helps protect people from feelings of death anxiety.

According to Terror Management Theory [4-6], the human cognitive capacities for symbolic thought and futureoriented thinking give rise to a potentially debilitating level of anxiety due to the recognition that personal mortality is inevitable and that death could occur suddenly and unexpectedly in myriad ways, many of which are outside of individuals' ability to control. Even with this great capacity for anxiety, people are able to pursue goal directed behavior because of the operation of a psychological buffer that manages this potential existential terror. The psychological anxiety buffer is composed of a cultural worldview and selfesteem. Cultural worldview refers to the consensually validated set of beliefs that imbue existence with order, stability, and meaning and define the means through which adherents to a particular belief system can keep themselves safe from harm, make a meaningful and enduring contribution to the world, and achieve literal and symbolic immortality. Self-esteem refers to the perception that one is making a valuable contribution to the world by living up to the standards of his or her cultural worldview. Pyszczynski et al. asserted that the death anxiety buffering function of cultural worldview and self-esteem rely on the assumption of a just world. If the standards by which culture defines 
meaningful and valuable actions are capricious or unfair then there can be no comfort in living up to these standards because there would be little confidence that adherence to these standards would lead to accumulating rewards and avoiding punishments [4].

Support for the idea that assumptions of fairness and justice are critical components of the psychological buffer against death anxiety comes from findings that mortality salience increased the monetary rewards participants recommended for heroes [7] and increased the severity of punishments participants recommended for moral and legal transgressors [7, 8]. In addition, exposure to visual stimuli associated with death, terrorist attack, and natural disaster, all of which likely primed thoughts of death, increased participants' concerns with justice, as evidenced by higher scores on a scale measuring how emotionally disturbed people were in response to the unfair allocation of rewards and punishment [9]. Further, experimentally induced thoughts of death have been shown to intensify defensive attributions such as victim blaming aimed at protecting belief in a just world. For example, Hirschberger reported that mortality salience increased attributions of blame to a driver who was seriously injured in an automobile accident [10].

Similarly, Landau et al. (study 5) reported that mortality salience increased participants' interest in reading negative information about an innocent victim who had been shot in a random attack. Presumably this negative information facilitated participants' ability to blame the victim, thereby re-establishing their perception of the world as just. However, this increased victim blaming elicited by mortality salience was limited to participants who were high in the need for personal structure, a personality trait associated with a rigid insistence on order and an intolerance of ambiguity [11]. Further, in study 6, Landau et al. found that reading about the victim of a random shooting who had been described in a positive manner increased the accessibility of death related thoughts compared to reading about a victim described in a negative manner, but only among participants high in personal need for structure [11]. Presumably this finding indicates that, among people with a rigid worldview, hearing about the undeserved suffering of another person undermines confidence in a just world leaving them vulnerable to existential anxiety.

These studies suggest that reminders of death can: increase concerns with justice, intensify interest in rewarding those who have acted heroically and punishing those who have acted unethically, and increase derogation of innocent victims who have been seriously injured in accidents. A perhaps more insidious possibility is that people's confidence in their own cultural worldview might be enhanced, thereby inoculating them against existential anxiety, when misfortunes and tragedies affect members of potentially threatening out-groups. Research by Hayes, Schimel, and Williams provided support for this possibility [12]. These authors reported that threatening the cultural worldview of Christian participants, by having them read about the increasing Muslim control over the city of Nazareth (the hometown of Jesus), made them more susceptible to existential anxiety as evidenced by an increase in death related cognitions. However, this threat was negated by having Christian participants read about the death of Muslims in an airplane crash. Ironically, reading about the death of others in a plane crash reduced the accessibility of death related thoughts. Hayes et al. interpret this finding as evidence that the death of Muslims actually strengthened the cultural worldview of Christian participants. Presumably this happened because Christian participants saw the disaster affecting Muslims as a just punishment of adherents to a different and potentially threatening cultural worldview and therefore found increased confidence and comfort in their own worldview.

The present study aimed to build on these findings and offer further support for the terror management function of belief in a just world by examining how belief in a just world would be affected by reading about a natural disaster impacting a religious out-group. If religious beliefs afford adherents a perceived sense of meaning and security in the world and if the existence of people with different religious beliefs threatens the confidence in the validity of people's beliefs making them vulnerable to existential anxiety, then evidence that bad things happen to proponents of opposing belief systems should reaffirm confidence in a just world. Specifically, mortality salience was expected to increase beliefs in a just world among Christian participants when they read about a natural disaster affecting Muslims.

An additional goal of the present study was to explore whether mortality salience might also increase emotional satisfaction and pleasure in response to natural disasters affecting religious out-groups. If the misfortune of culturally different others strengthens confidence in the validity of one's own cultural worldview and if such confidence is especially needed when thoughts of mortality are salient, then reminders of death should lead to positive emotional reactions when bad things happen to people with different and threatening belief systems. Previous research has shown that schadenfreude (malicious pleasure at the misfortune of others) is felt when bad things happen to politicians from rival political parties [13], national athletic rivals [14], and people who are perceived as deserving their misfortune [15]. Based on these findings, it seems that schadenfreude stems from in-group bias and the need to perceive the world as operating fairly. From the perspective of Terror Management Theory, both of these motives are subsumed under the broader goal of assuaging existential anxiety. Mortality salience has been shown to increase ingroup bias [16-18] and concerns with fairness [9]. Consequently, it seemed reasonable to expect that mortality salience would increase schadenfreude in response to the misfortunes of an out-group.

In the present study, Christian participants were primed to think about either their personal mortality or undergoing a painful dental procedure before reading about a natural disaster that destroyed either a Christian Church or an Islamic Mosque leaving the victims questioning their faith. Participants then completed measures of belief in a just world and schadenfreude. It was hypothesized that mortality salience relative to dental pain salience would lead to greater belief in a just world and more schadenfreude in response to reading about a natural disaster but only when it affected Muslims and not when it affected fellow Christians. 


\section{METHOD}

\section{Participants}

Undergraduate psychology students $(\mathrm{N}=129)$ received extra credit towards their course grade for study participation. Twelve participants were excluded from the analysis because they indicated that they did not believe in God, 26 participants were excluded because they did not answer the question about religious affiliation, and three additional participants were excluded because they did not complete all of the dependent measures. The remaining 88 participants all indicated that they believed in God and were Christians. These participants (44 men, 69 women, 1 unspecified gender) ranged in age from 18-30 years $(M=$ $19.9, S D=2.25)$, reported attending religious services an average of 3.71 times per month $(S D=4.17)$, and indicated on a scale from 1 (not at all) to 7 (extremely) that religion was considerably important in their lives $(M=5.68, S D=$ 1.48).

\section{Materials and Procedure}

Participants volunteered for a study exploring the link between personality traits and reactions to stories. Participants were randomly assigned to a mortality salience or dental pain salience condition. In the mortality salience condition, participants wrote responses to two essay questions concerning thoughts and feeling associated with their own death. In the dental pain salience condition, participants wrote responses to two essay questions concerning undergoing a painful dental procedure. These questions were embedded in a set of filler personality scales. All participants then completed the Positive and Negative Affect Scale [19] to insure any manipulation effects were not due to general negative affect. Next, participants read and answered questions about an innocuous passage [20] as mortality salience elicits greater effects when thoughts of death are no longer the focus of conscious attention [4]. Participants were randomly assigned to read one of two versions of a story created for this study (see Appendix). In the out-group target condition, the story described the destruction of a mosque in an earthquake. In the in-group target condition, the story described the destruction of a church in a tornado. Schadenfreude was measured by having participants rate, on a 7-point scale [1 (not at all) to 7 (very much)], the extent to which they felt happy, satisfied, pleased, sympathy, pity, sorry [21] and the extent to which they could not resist a smile and actually had to laugh a bit in response to the story [15]. Responses to the items sympathy, pity, and sorry were reversed scored before calculating an average schadenfreude score. This measure of schadenfreude had good internal consistency in the current sample (Chronbach's $\alpha=.77$ ).
Participants then completed the Just World Scale [22] on which they rated their agreement, [from 0 (strongly disagree) to 5 (strongly agree)], with 20 statements such as "Basically, the world is a just place." Higher scores on this measure indicate a greater tendency to believe in a just world. In the current sample, the internal consistency of the Just World Scale was somewhat low (Chronbach's $\alpha=.64$ ). Lastly, participants provided demographic information including their age, gender, religious affiliation, religious attendance, and the importance of religion in their lives.

\section{RESULTS}

The effect of the mortality salience manipulation and the type of target were assessed on two separate dependent variables: belief in a just world and schadenfreude. Each of these dependent variables was subjected to a Salience (mortality / dental pain) x Target (Christian / Muslim) ANCOVA with negative affect as a covariate.

\section{Belief in a Just World}

The analysis of belief in a just world revealed only the predicted Salience $\mathrm{x}$ Target interaction effect, $F(1,83)=$ $5.80, p=.019$ (see Table 1). To interpret this interaction effect, the simple effect of salience was examined for each type of target, again controlling for negative affect. When the targets of the natural disaster were Christians, the mortality salience manipulation had no effect on participants' belief in a just world, $F(1,83)=1.0, p=.320$. However, when the targets of the natural disaster were Muslims, participants in the mortality salience condition reported significantly higher levels of belief in a just world than did participants in the control condition, $F(1,83)=5.1, p=.027$. As an alternative way to interpret the interaction effect, the simple effect of target was examined at each level of salience, again controlling for negative affect. The type of target had no effect on belief in a just world when dental pain was salient, $F(1,83)=0.7, p=.405$, but when mortality was salient, participants who read about Muslim victims of a natural disaster reported significantly higher belief in a just world than did participants who read about Christian victims of a natural disaster, $F(1,83)=5.8, p=.018$.

\section{Schadenfreude}

The analysis of schadenfreude revealed only a statistically significant main effect for target, $F(1,83)=$ $11.2, p=.001$. Participants reported more schadenfreude in response to the natural disaster affecting Muslims $(M=2.35$, $S D=0.54)$ than in response to the natural disaster affecting Christians $(M=1.80, S D=0.89)$. The pattern of means (see Table 2) revealed no hint of the expected Salience x Target interaction, $F(1,83)=0.2, p=.693$.

Table 1. The effect of mortality salience and type of target on belief in a just world.

\begin{tabular}{|c|c|c|}
\hline & Mortality Salience $\boldsymbol{M}(\boldsymbol{S D})$ & Dental Pain Salience $\boldsymbol{M}(\boldsymbol{S D})$ \\
\hline \hline Disaster Affecting Christians & $49.87(8.11)$ & $51.51(8.69)$ \\
\hline Disaster Affecting Muslims & $57.00(9.11)$ & $50.88(8.99)$ \\
\hline
\end{tabular}


Table 2. The Effect of Mortality Salience and Type of Target on Schadenfreude.

\begin{tabular}{|c|c|c|}
\hline & Mortality Salience $\boldsymbol{M}(\boldsymbol{S D})$ & Dental Pain Salience $\boldsymbol{M}(\boldsymbol{S D})$ \\
\hline \hline Disaster Affecting Christians & $1.71(0.44)$ & $1.87(0.61)$ \\
\hline Disaster Affecting Muslims & $2.33(0.89)$ & $2.36(0.91)$ \\
\hline
\end{tabular}

\section{DISCUSSION}

As hypothesized, mortality salience did increase belief in a just world among Christian participants who read about Muslim victims of a natural disaster. This finding further documents the effect of mortality salience on the need to maintain a belief in a just world [9, 10] and the terror management perspective viewing belief in a just world as an important component of the psychological buffer against existential anxiety. The results of the present study are also consistent with previous research showing that the misfortune of out-groups can inoculate in-group members against potential death anxiety [12].

Although mortality salience increased belief in a just world in response to an out-group's misfortune it did not significantly decrease belief in a just world in response to an in-group's misfortune. It is possible that participants responded to the natural disaster affecting fellow Christians by spontaneously using a number of strategies to protect their belief in a just world, including viewing the victims as deserving of their fate by questioning their level of faith or their adherence to Christian ethical standards. Additionally, they could have reframed the issue as consistent with ultimate justice by viewing the disaster as a test of faith, with the idea that God would somehow justly reward Christian victims (e.g., stronger faith, eternal reward). None of these possible reactions were measured in the current study but might be fruitful avenues for future research.

The results of the present study also add to the literature on schadenfreude. Participants in the present study reported more schadenfreude when a natural disaster affected Muslims than when it affected Christians. This finding is consistent with previous research documenting schadenfreude in response to the misfortune of out-groups in the domains of politics [13] and athletics [14] and extends the phenomenon to religious out-groups. Although participants did report more schadenfreude in response to the misfortune of an out-group rather than the misfortune of an in-group, mortality salience did not have the anticipated effect of intensifying this tendency. The failure to observe an effect of mortality salience on schadenfreude may have been a consequence of the limited power in this study due to the small sample size. However, an examination of the means shows almost no difference between the mortality salience and control conditions for either the Christian or Muslim target, suggesting that the null finding may not be merely a lack of power.

Further, there are theoretical reasons the potential effect of mortality salience on schadenfreude may have been masked in the present study. For example, social desirability motives may prevent people from honestly reporting feelings of schadenfreude. People are usually reluctant to admit taking pleasure in the suffering of others because it violates societal expectations of sympathetic reactions [23]. The reported levels of schadenfreude in all four cells of the current experiment were below 2.4 on a 7-point scale. This may reflect the fact that social desirability suppressed reported levels of schadenfreude, thereby masking any effect of mortality salience.

Consistent with this interpretation, previous research has shown that social desirability masks the effects of mortality salience on the expression of prejudiced attitudes toward outgroups [24]. In a sample of non-Jewish American university students, reminders of death led to increased anti-Semitism. However, this effect only occurred when participants were in a bogus pipeline condition, such that they were led to believe they were connected to a lie detector that would catch them if they tried to under-report their prejudice [24]. This finding illustrates that mortality salience increases negative attitudes towards dissimilar others, but participants are sometimes reluctant to report these negative attitudes, making the mortality salience effects difficult to observe under normal circumstances. Future research might address this problem by employing the bogus pipeline paradigm, measuring individual differences in social desirability, or by exploring schadenfreude in more socially acceptable domains, such as athletics.

An alternative explanation for the lack of effect of mortality salience on schadenfreude in the present study is that mortality salience may have stimulated competing psychological motives in participants. While Christian participants might have felt satisfied by the misfortune of Muslims because it strengthened their convictions about the validity of their religious belief system, they might have also been compelled to live up to the standards of their Christian worldview, which places a premium on compassion. The specific nature of mortality salience effects have been shown to vary depending on which components of cultural worldview are most accessible due to dispositional (individual differences) or situational (priming) factors [2527]. For example, priming Christians with Biblical scriptures urging compassion negated the typical increase in hostility towards worldview-threatening others observed in response to mortality salience [28]. Future research might examine how the accessibility of the Christian value of compassion (either due to individual differences or situational priming) could moderate the effects of mortality salience on reactions to the misfortunes of religious out-groups. 
In conclusion, the present study showed that mortality salience increased belief in a just world when a religious outgroup was the victim of a natural disaster. This finding suggests the possibility that learning about the misfortunes of cultural out-groups might actually bolster the confidence of in-group members in their cultural worldview, thereby enhancing their protection against potential existential anxiety. The misfortunes of people with different and potentially threatening belief systems may strengthen beliefs in a just world by fostering a sense of special protection in which people with similar beliefs are perceived as being safe from harm, whereas those with different beliefs are not.

\section{APPENDIX}

\section{Out-Group Condition}

Earthquake Wreaks Financial and Spiritual Havoc in $\underline{\text { Pakistan }}$

An earthquake struck Kashmir damaging dozens of buildings and destroying a Mosque. The most significant damage occurred in the Pakistan controlled area Muzaffarabad. Although no one was seriously hurt, the earthquake caused substantial damage to many of the buildings in the area. Although the financial cost of the earthquake will be substantial, there will also likely be a spiritual cost, as the Jama Haman Wali Mosque was completely demolished. Worshippers at this mosque were known for their religious piety and devout adherence to Islam. Many of the Muslims who worshiped there are struggling with the question of why Allah would allow this to happen to them.

\section{In-Group Condition}

Tornado Wreaks Financial and Spiritual Havoc in Arkansas

A tornado touched down in central Arkansas damaging dozens of buildings and destroying a church. The most significant damage occurred in Van Buren County. Although no one was seriously hurt, the twister caused substantial damage to many of the buildings in the area. Although the financial cost of the tornado will be substantial, there will also likely be a spiritual cost, as the Foursquare Nondenominational Christian Church was completely demolished. Worshippers at this church were known for their religious piety and devout adherence to Christianity. Many of the Christians who worshiped there are struggling with the question of why God would allow this to happen to them.

\section{CONFLICT OF INTEREST}

The authors confirm that this article content has no conflict of interest.

\section{ACKNOWLEDGEMENTS}

Declared none.

\section{REFERENCES}

[1] Dudek M. As horrible as the Washington tornado was, some ask why it wasn't deadlier. Chicago Sun Times. December 8, 2013. Retrieved from http://www.suntimes.com/news/metro/24214626418/as-horrible-as-the-washington-tornado-was-some-ask-why-itwasnt-deadlier.html

[2] Friedman M. God's wrath caused Katrina. Time. September 16, 2011. Retrieved from http://content.time.com/time/specials/packages/article/0,28804,1953778_1953776_1953771,00.html \#ixzz2nBzlMKc5

[3] Lerner MJ. The belief in a just world: a fundamental delusion. New York: Plenum 1980.

[4] Pyszczynski T, Greenberg J, Solomon S. Why do we need what we need? A terror management perspective on the roots of human social motivation. Psychol Inq 1997; 8: 1-20.

[5] Solomon S, Greenberg J, Pyszczynski T. Terror management theory of self-esteem. In: Snyder CR, Forsyth D, Eds. Handbook of social and clinical psychology: The health perspective, Pergamon Press 1991; pp. 21-40.

[6] Solomon S, Greenberg J, Pyszczynski T. The cultural animal: Twenty years of terror management theory and research. In Greenberg J, Koole SL, Pyszczynski T, Eds. Handbook of experimental existential psychology. New York: Guilford 2004; pp. 13-34.

[7] Rosenblatt A, Greenberg J, Solomon S, Pyszczynski T, Lyon D. Evidence for terror management theory I: The effects of mortality salience on reactions to those who violate or uphold cultural values. J Pers Soc Psychol 1989; 57: 681-90.

[8] Florian V, Mikulincer M. Fear of death and the judgment of social transgressions: A multidimensional test of terror management theory. J Pers Soc Psychol 1997; 73: 369-80.

[9] Kastenmuler A, Greitemeyer T, Hindocha N, Tattersall AJ, Fischer, P. Disaster threat and justice sensitivity: A terror management perspective. J App Soc Psychol 2013; 43: 2100-6.

[10] Hirschberger G. Terror management and attributions of blame to innocent victims: reconciling compassion and defensive responses. J Pers Soc Psychol 2006; 91: 832-44.

[11] Landau MJ, Johns M, Greenberg J, et al. A function of form: Terror management and structuring the social world. J Pers Soc Psychol 2004; 87: 190-210.

[12] Hayes J, Schimel J, Williams TJ. Fighting death with death: The buffering effects of learning that worldview violators have died. Psychol Sci 2008; 19: 501-7.

[13] Combs DJY, Powell CAJ, Schurtz DR, Smith RH. Politics, schadenfreude, and ingroup identification: The sometimes happy thing about a poor economy. J Exp Soc Psychol 2009; 45: 635-46.

[14] Leach CW, Spears R, Branscombe NR, Doosje B. Malicious pleasure: Schadenfreude at the suffering of another group. J Pers Soc Psychol 2003; 84: 932-43.

[15] van Dijk WW, Goslinga S, Ouwerkerk JW. Impact of responsibility for a misfortune on schadenfreude and sympathy: Further evidence. J Soc Psychol 2008; 148: 631-36.

[16] Arndt J, Greenberg J, Pyszczynski T, Solomon S. Subliminal exposure to death-related stimuli increases defense of the cultural worldview. Psychol Sci 1997; 8: 379-85.

[17] Greenberg J, Pyszczynski T, Solomon S, et al. Evidence for terror management theory II: the effects of mortality salience on reactions to those who threaten or bolster the cultural worldview. J Pers Soc Psychol 1990; 58: 308-18.

[18] Nelson LJ, Moore DL, Olivetti J, Scott T. General and personal mortality salience and nationalistic bias. Pers Soc Psychol Bull 1997; 23: 884-92.

[19] Watson D, Clark L, Tellegen A. Development and validation of brief measures of positive and negative affect: The PANAS scales. J Pers Soc Psychol 1988; 54: 1063-70.

[20] Greenberg J, Pyszczynski T, Solomon S, Simon L, Breus M. Role of consciousness and accessibility of death-related thoughts in mortality salience effects. J Pers Soc Psychol 1994; 67: 627-37.

[21] Feather NT, Nairn K. Resentment, envy, schadenfreude, and sympathy: effects of own and others' deserved or undeserved status. Aust J Psychol 2005; 57: 87-102.

[22] Rubin Z, Peplau LA. Who believes in a just world? J Soc Issues 1975; 31: 65-89. 
[23] Smith RH. The joy of pain: Schadenfreude and the dark side of human nature. New York: Oxford 2013.

[24] Cohen F, Jussim L, Harber KD, Bhasin G. Modern anti-Semitism and anti-Israeli attitudes. J Pers Soc Psychol 2009; 97: 290-306.

[25] Jonas E, Martens A, Niesta Kayser D, Fritsche I, Sullivan D, Greenberg J. Focus theory of normative conduct and terrormanagement theory: the interactive impact of mortality salience and norm salience on social judgment. J Pers Soc Psychol 2008; 95: $1239-51$.

[26] Arndt J, Cook A, Routledge C. The blueprint of terror management: understanding the cognitive architecture of psychological defenses against the awareness of death. In:
Greenberg J, Koole SL, Pyszczynski T, Eds. Handbook of experimental existential psychology. New York: Guilford 2004; pp. 35-53.

[27] Greenberg J, Simon L, Pyszczynski T, Solomon S, Chatel D. Terror management and tolerance: Does mortality salience always intensify negative reactions to others who threaten one's worldview? J Pers Soc Psychol 1992; 63: 212-220.

[28] Rothschild Z, Abdollahi A, Pyszczynski T. Does peace have a prayer? Effects of mortality salience, religious fundamentalism, and compassionate values on hostility toward the out-group in the United States and Iran. J Exp Soc Psychol 2009; 45: 816-27.

(c) Bassett and Cate; Licensee Bentham Open.

This is an open access article licensed under the terms of the Creative Commons Attribution Non-Commercial License (http://creativecommons.org/licenses/by-nc/3.0/) which permits unrestricted, non-commercial use, distribution and reproduction in any medium, provided the work is properly cited. 